\title{
Analyzing the Impact of Teacher Talk on English Grammar Learning: With Correlation to the Procedures in Classroom Interaction
}

\author{
Asmaa M. Alkhazraji \\ The British University in Dubai, Dubai, UAE
}

\begin{abstract}
The main purpose of this research paper is to explore the impact of Teacher Talk in English Grammar Acquisition through interaction procedures in the classroom. Through a Conversation Analysis perspective, three extracts from audio- recording were analyzed and transcribed. These extracts focused on the Teacher Talk in Grammar Teaching through interaction with the students. The findings show that Teacher Talk improves the learning of English Grammar. When teachers engage in small talk with students, the students acquire the rules of grammar easily through 'Turn Management' and the 'Next Speaker Selection' Procedures. Thus, these procedures do not only improve teaching process, but also accredit students who learn English as the second language correctly and accurately. The findings of the study underline opportunities for further research.
\end{abstract}

Index Terms - teacher talk, procedures, grammar teaching, grammar learning, language acquisition

\section{INTRODUCTION}

Grammar is an integral part of mastering the structures of the English language. It provides a good opportunity for learners to understand the correct usage of the language and develop their interpersonal communication. Since Grammar is an integral part of Language Acquisition, teachers should know how to teach grammar. It allows students to communicate meaningful sentences. Syntax instruction as a section Linguistic Teaching aids students to improve their LSRW skills. Syntax is an indispensable tool for the accomplishment of oral interaction (Hinkel \& Fotos, 2002). In addition, it concentrates on consciousness-raising form, which mainly presguaents at the level of understanding a topic (Fotos, 1993; Ellis, 1993; Fotos \& Ellis, 1991; \& Nassaji \& Fotos, 2011).

The rules of grammar do not only govern words, but also the sentence forms in English language. These rules that elucidate the correct way of connecting words and phrases together to produce a sentence called Syntax. Syntax and Grammar are the basis of the language. Thus, they enable people to express themselves and provide sentences that are meaningful (Thornbury, 1999; Zhang, 2009).

Most professionals in Applied Linguistics such as Mart (2013) and Wang (2010) agree that more light should be shed on Grammar Instruction in the classroom. Nassaji and Fotos (2011) assert that the Teaching of Grammar ought not to be disregarded in ESL classrooms. This is because it is one of the crucial ways which facilitates Language Learning effectively. Syntax Instruction is considered to be the foundation in Language Learning and Teaching. Thus, Linguists believe that Grammar is in the foreground of Language Teaching and Learning.

The effective manner of Grammar Instruction with appropriate time spacing is a question that needs to be proved. Syntax Instruction helps the students improve their language structure. The process of teaching occurs when the students face a problem relating to the syntactic rules in their discourse production. This explanation does not mean providing the rules only to the students, but also drawing their attention to a particular form or structure. This instruction can be successful if it occurs in a communicative context. Interaction includes content more than just syntax (Hinkel \& Fotos, 2002).

Teachers use Interaction process for teaching Second Language to Learners. They apply grammatical rules (Walsh, 2011), through activities and procedures to achieve Language Learning (Benati \& Lee, 2008). Teacher selects the next speaker from the students to talk, answer the questions, direct the talk (i.e if the talk need to continue or not), and control the forms used by the student in answering the question. They also evaluate the students' answers in terms of Grammatical Accuracy (Mehan, 1979; Seedhouse, 2004; \&Walsh, 2011).

Although many studies such as Cakır (2011), Deng and Lin's (2016), and Ilin et al. (2013) focus on Grammar Teaching, none of them concentrate on how Grammar can be learnt and acquired verbally through procedures used in Teacher Talk. This paper aims to explore the impact of Teacher Talk in Grammar Acquisition under a Communicative Context. The objective of the study was to find out whether social interaction procedures in EFL Teacher Talk impact the Learning of Grammar.

\section{LITERATURE REVIEW}


Celce-Murcia and Hilles (1988) define Grammar as rules that govern the morphology and the syntax of a language. It focuses on the relation between the components of a word and words in a sentence. Carter and McCarthy (2006) connect the morphology (word structure) and syntax (sentence arrangement) the basics of grammar, to the form of utterances and sentences.

Grammar not only dominates the form of sentences, but also makes the sentences meaningful (Thornbury, 1999). The sentences are utilized for communicative purpose. Efficient and clear communication is always correlative with correct grammar (Nassaji \& Fotos, 2011). Therefore, Grammar is used for facilitating comprehension and to avoid misunderstanding (Savage et al., 2010). Grammar helps students comprehend the grammatical facts (Uysal \& Bardakci, 2014). That's why it focuses on the unity of the sentences (Richards \& Reppen, 2014).

Teaching of grammar is an essential component in Language Learning (Ellis, 2006). Teaching of syntax raises awareness on the rules of grammar, and allows learners to use the rules in a more acceptable way (Zhang, 2009). It allows learners build clear and understandable discourse (Mart, 2013), and to identify and correct the mistakes in sentence structures. It also directs learners avoid any breakdowns in their conversations and communications (AlMekhlafi \& Nagaratnam, 2011). Besides, it aids learners acquire and use language naturally. Since Grammar instruction enables students know how grammar is used, it makes them learn the language naturally. This provides learners with an opportunity to have a potential, limitless vocabulary in the language (Richards \& Reppen, 2014).

There are two approaches of Grammar Instruction: Focus on Form and Focus on Meaning. Focus on Form (FOF) approach is as an instruction used by the teachers to bring students' attention to a rule in a meaningful communicative context (Doughty \& Williams, 1998). On the Contrary, Focus on Meaning (FOM) is another approach that draws learners' attention to the meaning. It tends to improve learners' ability to acquire language in a natural process through the classroom situation (Krashen \& Terrell, 1983).

Both these approaches enable students learn communication through grammatical rules. FOF enables learners acquire language faster with higher levels of accurate language production and elongated usage of form than focus on meaning (Uysal \& Bardakci, 2014). Whereas, learners take a longer tenure for language production in Focus On Meaning instruction (Ellis, 2006; Nassaji \& Fotos, 2004).

Communication with children is different than with adults. Teachers need not use Grammar structures when talking with adults, while with children they simplify the language in order to facilitate learning process (Ferguson, 1977). Teacher Talk is the main component of interaction with students in the classroom. It is a procedure used to improve both interaction and learning in the classroom (Harmer, 2007).

The importance of Teacher Talk lies in enabling learners to understand the grammatical rules and distinguish the differences between their first and second languages (Ferguson, 1977). This can help in their knowledge on the rules of the Second Language, improve gradually and use them easily (Verplaetse \& Hall, 2000). Teacher Talk also enables students participate and continue the interaction. (Sert, 2015). Therefore, Teacher Talk is described as 'A Distinct Sociolinguistic Register' (Chaudron, 1988, p.54).

Classroom interaction follows the IRF pattern which is Initiation, Response, and Feedback. The teacher usually takes his/her place in Initiation and Feedback. During the Initiation, s/he acts as a leader. In the response mode, students are followers. At the time of Feedback, the instructor acts as an Evaluator of students' answers (Cook, 2008; Sharpe, 2008). Feedback credits the accuracy of the students' production in the target language. Feedback is given through two methods, Positive Feedback and Negative Feedback. The Positive Feedback includes praise and repetition of the students' correct responses. Negative Feedback depends on the explanation of syntax and modelling the correct answer to the learners (Chaudron, 1988).

Perhaps, the most useful model for analyzing this dimension of classroom language is the earlier model devised by Sinclair and Coulthard (1975) which clearly identified the IRF exchanges as being the most typical discourse pattern in most classrooms. A theory which can be build on this model is Conversation Analysis (henceforth CA). The central focus of CA is adjacency pairs, in which the first pair and the second pair are mutually constrained. The utterances in adjacency pairs are mutually dependent so that, for example, a question expects a response, and the response expects either another question or acknowledgement (Schegloff \& Sacks, 1973).

The most significant factor of IRF methodology is to facilitate language learning and classroom talk interaction. It assists teachers and students to talk and achieve turn exchange successfully (Schegloff, 1982). It also empowers the teacher to direct the topic flow and receive a suitable answer (Sharpe, 2008). Teachers in this pattern can extend learning space by practicing (Sert, 2015). The IRF sequence also provides sociolinguistic competence. Then, this sequence works on learners' utterances and supplies confirmation of engagement and thinking (Verplaetse \& Hall, 2000).

In order to extend the IRF sequences exchange, teachers in their initiation roles use 'Next Speaker Selection' procedure in their interaction with the students. This procedure means that the teachers choose the next student to talk to or answer their question in order to continue the sequential conversation (Seedhouse, 2004). Mortensen (2008) describes this procedure allocating turns of the learners which access their participation in the class interaction. It ensures that all the students in the class participate in the interaction.

Another procedure used in the classroom is 'Turn Management'. This allows the teachers control over the questions as well as the interaction. The teacher decides to continue the talk or not, but also over the form of Scaffolding 
questions that the learners should reply to (Seedhouse, 2004; Walsh, 2011). The role of teachers' management is to guarantee the learners opportunities of participation in the interaction. This role contributes to improve the Language Learning Process (Mortensen, 2008). Sacks et al. (1974) add that the power of teachers manages all the sections of the classroom conversation which is characterized differently from ordinary talk.

The function of Teacher Talk utilizes as an interaction process that makes the understanding of a topic easy (Ellis, 1985). The interactive condition in classroom is the primary element of Language Input and Acquisition (Verplaetse \& Hall, 2000). Chaudron (1988) clarifies that through interaction, the teacher's language structure can be deconstructed by students and they can acquire meaning from the events of the classroom. Also, interaction enables students to combine their own talking with the Teacher Talk. This leads to the extended speech communication between the instructor and students. Zhang (2012) adds that Teacher Talk through classroom communication makes certain changes in the speech of their class; this includes alteration in students' speech, syntax, and lexicon.

\section{METHODOLOGY}

This explanatory paper follows Conversational Analysis perspective. It explores the impact of Teacher Talk in English Grammar Learning through interaction in the classroom.

\section{A. Data Collection}

This study experiments on Teacher Talk. The talk occurs between teacher and learners in the class during the Grammatical Instruction. All of the lectures were recorded, but only Grammar Instruction was analyzed. Six hours was recorded of classrooms discourse in three classes. Audio-digital recording was used for collecting data in a private school in Dubai. The recorder was placed on the teacher's table and on the students' tables when the teacher divided them into groups. The data was listened to many times before transcribing carefully and accurately.

\section{B. Participants and Setting}

Three English teachers having two to five years of experience, participated in the current study. The teachers were from both genders and were native speakers of the English Language. Since most of the students were from United Arab Emeritus and Middle East, their first language was Arabic. The students' age was between five to six years. Both boys and girls participated in the study. They also had different language proficiency, and their number arranged 24-27 in each class. This school followed British curriculum. There was no specific textbook used in this school. The teachers provided their learners information about the topic.

\section{AnAlysis OF DATA}

Teacher Talk is utilized in social interaction with the learners as a natural conversation between the teacher and the students. This section clarifies how Turn Talking is controlled by the teacher and how this exchange contributes in constructing potential learning.

Extract 1:

Tr: What is your favorite toy?

St: Batman

Tr: Wow

Tr: Can you say

Tr: <I would like to play with Batman>

St: I would like to play with Batman

Tr: Wonderful

Tr: And who do you like to play with

St: My brother

Tr: What's your brother's name

St: Nasser

Tr: Nasser

Tr: Can you say

Tr: <My brother's name is Nasser $>$

St: My brother's name is Nasser

Tr: Excellent, good boy

In Extract 1, the teacher helped the students produce correct grammatical sentence through Turn-Taking between the teacher and the student in a social situation. The discussion in this classroom was initiated by the teacher through scaffolding questions, as in lines 1, 8, and 10. These questions aimed to develop the student's productivity, although he produced short answers in lines 2, 9, and 11. The teacher posed some questions, for providing clues to the students and kept the interaction process on-going. Furthermore, in lines 4 and 13, the teacher extended the learning space with this question 'Can you say'. This means that she replaced the student's short answers in lines 2 and 11 by the sentences which had an appropriate grammatical form in lines 5 and 14 to teach the student how to answer with clarity. In addition, the teacher encouraged the student to talk and use the language correctly. Positive feedback was given by the 
teacher in lines 3, 7, and 16 for their correct responses in lines 6 and 15. The 'next speaker selection' procedure is in the following extract.

Extract 2:

Tr: What happens at the start of the story

St1: Frog and am.... Super Duck looking for goat

Tr: Where was he, Mansour

St2: In the shade

Tr: In the shade

Tr: What was he doing in the shade

St2: making his kite

Tr: that's great

Tr: Do you remember, Hind, what was the problem

St3: There wasn't any wind

Tr: There was no wind

In Extract 2, the teacher employed the 'Next Speaker Selection' procedure in terms of Turn Allocation. The teacher extended the conversation through choosing different students to answer her questions. This procedure provided opportunities for practice talking to all the students. In lines 3 and 9, the teacher allocated the students' name not only to gain additional information about the story, but also to measure their language usage through social interaction. Also, the teacher extended the conversational space with the next speaker through asking him question in line 6 . This procedure succeeded in engaging the students in the sequential discussion and encouraged them use the language in a flexible way, as evidenced by the students' responses in lines 4,7 , and 10 . Consequently, the teacher improved the learning of grammatical rules by providing evaluation of the students' answers in lines 5 and 8 , or as a correction line 11. The 'turn-management' procedure is in the extract 3 below.

Extract 3:

Tr: Now let's see ((show picture))

Tr: Who helped him, Lyla

St1: The sheep and the goat

Tr: Did they help Super Duck

St1: Yeah, but he bumped

Tr: Ah... who bumped

St1: Super Duck and the frog

Tr: Where did they bump

St1: They bumped into a tree

Tr: They bumped into a tree

Tr: Good gir::1, well done, excellent

Tr: What do you think is going to happen in the end, Ali

St2: He jumped on the ground

Tr: he jumped on the ground

Tr: Well, and then what happened in the end

Tr: Do you think they were all happy in the end, Rana

St3: Yes

Tr: Yes they were

Tr: Why

St3: he got down

Tr: who did get down

St3: Super Duck got down

Tr: Good boy, excellent

In extract 3, the teacher discussed a story with the students in the class through asking questions, in order to increase the space of learning and talking naturally. The 'Turn Management' was used by the teacher through managing both the questions' forms and the direction of the student's speech. In detail, the effective questions asked by the teacher in lines $2,4,6$, and 8, received the suitable answers from the learners in lines 5 and 9. Although the teacher provided the required answers for the student in lines and 7, these answers were not completed because had not had a finite verb. Besides, the teacher succeeded in controlling the direction of the next speaker's speech and extending the learning space as in lines 12,16 , and 19, through the student's grammatically correct answers in lines 13,20 , and 22 . In this extract, the teacher controlled the forms of questions. This means, she prompted the students use the past tense in their answer, because of the tense of the questions. Additionally, the teacher in line 18 managed the conversation in providing the student the feedback as a correction for their incomplete response in line 17. Finally, the teacher ended the discussion with positive evaluation as in lines 11 , and 23, because of the good performances of the students in lines 5, 9, 13, and 20. 
In terms of IRF patterns, Teacher Talk is the main part. This section discusses the impact of Teacher Talk in the classroom step by step. It discusses how the Teacher Talk enables the students acquire the language properly and accurately in a social situation. This occurs through the two procedures used in the present study. The first one is the 'Next Speaker Selection' procedure similar to the outcomes of Seedhouse (2004) and Mortensen (2008), which classify it as part of the 'Turn-Allocation' according to Sacks et al. (1974, p.703). It is found that this procedure plays an essential role in transferring the sequential turns in the classroom interaction (extract 2 lines 3 and 9). The following example from extract 3 line 16 illustrates this procedure:

Example:

Tr: Do you think they were all happy in the end, Rana

St3: Yes

Tr: Yes they were

In this example, the second student allocated as the next speaker was selected by the teacher. This procedure enables the teacher not only to continue the sequence of the classroom conversation, but also to evaluate the students' grammatical knowledge through their usage of the language. Similarly, Teacher Talk promotes the language learning of the students by helping them to produce correct sentences. This procedure is called, according to Schegloff and Sacks (1973), Adjacency Pairs, which is categorized into two parts: the first one is produced by the teacher, and the second part is produced by the student.

The second procedure used in the classroom interaction is 'Turn Management'. The teacher guides the students through the forms of the questions (to derive answers from the students), and then directs their speech. That is why the 'Turn Management' is required in acquiring grammatical rules through the interaction process. This procedure is determined (in extract 3 lines 2, 4, 6, 8, 12, 16, 19, 21) in which the teacher, through posing questions in the past tense, directs the students' answers to be in the past tense. This procedure is not limited to this goal only, but enables the teacher also to manage the participation of the students in the classroom talk. It keeps the flow of the conversation and enhances learning, (as shown in extract 2 lines 3 and 9; and extract 3 lines 2 and 12). In a similar sense, Emmer and Stough (2001) assert that in order to achieve the learning outcomes, managing the engagement of the learners in classroom talk is indispensable. The findings of Mortensen (2008), Sacks et. al. (1974), Seedhouse (2004), and Walsh (2011) reinforce the finding of the current study.

\section{PedAGOGICAL IMPLiCATION}

Though there are numerous methods of teaching English, quite a few are applicable in the current scenario. They are 'Turn-Taking' of Teacher Talk, using the 'Next Speaker Selection' and 'Turn Management' procedures to aid learners acquire and produce the target language in a social situation. These procedures not only provide the students an opportunity to use the language through talking, but also enable the teachers to channelize the verbal use by allocating turns to the students. They also endow the teachers to control the sequence of the conversation in a flexible way. The 'Turn Management' procedure also allows the teacher to direct and affirm the students' answers.

\section{CONCLUSION}

This research paper tries to examine the effect of Teacher Talk in English grammar Learning. It is exemplified that Teacher Talk during social situations stimulates Acquisition of the Grammar rules naturally through, the two main procedures: 1. Turn Management and 2. Next Speaker Selection. 'Turn Management' channelizes the conversation through scaffolding questions) and 'Next Speaker Selection' involves all the students in the classroom to share views about the topic and enhance their language usage. Both these procedures succeed not only in allowing the conversation to flow naturally, but also in developing the learning process. Consequently, these effective outcomes can be recommended to the ESL and EFL teachers.

There are a few limitations to this study. This study was conducted in a particular educational place in Dubai. The English teachers were native speakers of English Language. These factors do not facilitate further study. Studies also can be carried on the same field but in another stream. Since Grammar is acquired through oral interaction (Mazeland, 2013), interview method can be used for data collection. It can be considered as 'Talk-in-Interaction' in which TurnTaking takes place through Question and Answer method (Packett, 2005, p. 236).

\section{REFERENCES}

[1] Al-Mekhlafi, A. M. \& Nagaratnam, R. P. (2011). Difficulties in teaching and learning grammar in an EFL context. International Journal of Instruction, vol. 4(2), pp. 69-92.

[2] Cakır, İ. (2011). Problems in teaching tenses to Turkish learners. Theory and Practice in Language Studies, vol. 1 (2), pp. 123127.

[3] Carter, R. \& McCarthy, M.J. (2006). Cambridge grammar of English: A comprehensive guide: Spoken and written English grammar and usage. Cambridge: Cambridge University Press.

[4] Celce-Murcia, M. \& Hilles, S. (1988). Techniques and resources in teaching grammar. 10th edn. New York: Oxford University Press. 
[5] Chaudron, C. (1988). Second language classrooms: Research on teaching and learning. 6th edn. Cambridge: Cambridge University Press.

[6] Cook, V.J. (2008). Second language learning and language teaching. 4th edn. London: Hodder Education.

[7] Deng, F. \& Lin, Y. (2016). A comparative study on beliefs of grammar teaching between high school English teachers and students in china. English Language Teaching, vol. 9 (8), pp. 1-10.

[8] Doughty, C.J. \& Williams, J. (eds). (1998). Focus on form in classroom second language acquisition. 4th edn. Cambridge: Cambridge University Press.

[9] Ellis, R. (1985). Understanding second language acquisition. 4th edn. Oxford: Oxford University Press.

[10] Ellis, R. (1993). Talking shop: Second language acquisition research: How does it help teachers? ELT Journal, 47 (1), pp. 3-11.

[11] Ellis, R. (2006). Current issues in the teaching of grammar: An SLA perspective. TESOL Quarterly, vol. 40 (1), pp. 83-107.

[12] Emmer, E.T. \& Stough, L.M. (2001). Classroom management: A critical part of educational psychology, with implications for teacher education. Educational Psychologist, vol. 36 (2), pp. 103-112.

[13] Ferguson, C. (1977). 'Baby talk as a simplified register', in C. Snow \&, C. Ferguson (eds). Talking to Children; Language Input and Acquisition. Cambridge: Cambridge University Press, pp. 209-235.

[14] Fotos, S. (1993). Consciousness-raising and noticing through focuss on form - grammar task- performance versus formal instruction. Applied Linguistics, vol. 14 (4), pp. 385-407.

[15] Fotos, S., \& Ellis, R. (1991). Communicating about grammar: A task-based approach. TESOL Quarterly, vol. 25 (4), pp. 605628.

[16] Hinkel, E. \& Fotos, S. (2002). New perspectives on grammar teaching in second language classrooms. United States: Lawrence Erlbaum Associates.

[17] Harmer, J. (2007a). How to teach English. Essex:Pearson Education Limited.

[18] İlin, G., Kutlu, Ö. \& Kutluay, A. (2013). An action research: Using videos for teaching grammar in an ESP class. Procedia Social and Behavioral Sciences, vol. 70, pp. 272-281.

[19] Krashen, S.D. \& Terrell, T.D. (1983). The natural approach: Language acquisition in the classroom. Hayward, Calif: Alemany Press.

[20] Mart, Ç.T. (2013a). Teaching grammar in context: Why and how? Theory and Practice in Language Studies, vol. 3 (1), pp. $24-$ 129.

[21] Mazeland, H. (2013). 'Grammar in conversation', in T. Stivers \& J. Sidnell (eds). The handbook of conversation analysis. Malden, MA: Wiley-Blackwell, pp. 475-491.

[22] Mehan, H. (1979). Learning lessons: Social organization in the classroom. Cambridge, MA: Harvard University Press.

[23] Mortensen, K. (2008). Selecting next speaker in the second language classroom: How to find a willing next speaker in planned activities. Journal of Applied Linguistics, vol. 5 (1), pp. 55-79.

[24] Nassaji, H. \& Fotos, S. S. (2004). Current developments in research on the teaching of grammar. Annual Review of Applied Linguistics, vol. 24, pp.126-145.

[25] Nassaji, H. \& Fotos, S.S. (2011). Teaching grammar in second language classrooms: Integrating form-focused instruction in communicative context. New York: Routledge.

[26] Packett, A. (2005). 'Teaching patterns of interaction in English for specific purposes', in K. Richards \& P. Seedhouse (eds). Applying conversation analysis. Basingstoke: Palgrave Macmillan, pp. 235-250.

[27] Richards, J.C. \& Reppen, R. (2014). Towards a pedagogy of grammar instruction. RELC Journal, vol. 45 (1), pp. 5-25.

[28] Sacks, H., Schegloff, E.A. \& Jefferson, G. (1974). A simplest Systematics for the organization of turn-taking for conversation. Language, vol. 50 (4), pp. 696-735.

[29] Savage, K. L., Bitterlin, G. \& Price, D. (2010). Grammar matters: Teaching grammar in adult ESL programs. New York: Cambridge University Press.

[30] Schegloff, E. A. (1982). 'Discourse as Interactional Achievement: Some Uses of "uhhuh" and Other Things that Come between Sentences', in D. Tannen (ed). Analyzing Discourse, Text, and Talk. Washington, DC: Georgetown University Press, pp. 71-93.

[31] Schegloff, E.A. \& Sacks, H. (1973). Opening up closings. Semiotica, vol. 8 (4), pp. 289-327.

[32] Seedhouse, P. (2004). The interactional architecture of the language classroom: A conversation analysis perspective. Malden, MA: Blackwell Publishing.

[33] Sert, O. (2015). Social interaction and L2 classroom discourse. United Kingdom: Edinburgh University Press.

[34] Sharpe, T. (2008). How can teacher talk support learning? Linguistics and Education, vol. 19 (2), pp. $132-148$.

[35] Sinclair, J. \& Coulthard, M. (1975). Towards an analysis of discourse: The English used by teachers and pupils. London: Oxford University Press.

[36] Thornbury, S. (1999). How to teach grammar (how to...). 1st edn. England: Pearson Education Limited.

[37] Uysal, H.H., Object, O. \& Bardakci, M. (2014). Teacher beliefs and practices of grammar teaching: Focusing on meaning, form, or forms? South African Journal of Education, vol. 34 (1), pp. 1-16.

[38] Verplaetse, L.S. \& Hall, J.K. (2000). Second and foreign language learning through classroom interaction. London: Lawrence Erlbaum Associates.

[39] Walsh, S. (2011). Exploring classroom discourse: Language in action. London: Routledge.

[40] Wang, S. (2010). The significance of English grammar to middle school students in china. Journal of Language Teaching and Research, vol. 1 (3), pp. 313-319.

[41] Zhang, J. (2009). Necessity of grammar teaching. International Education Studies, vol. 2 (2), pp. 184-187.

[42] Zhang, P. (2012). Interactive patterns and teacher talk features in an EFL reading class in a Chinese University - A case study with communicative teaching method. Theory and Practice in Language Studies, vol. 2 (5), pp. 980-988. 
Asmaa M. Alkhazraji has BA degree in Education- English language from Baghdad University. She has obtained master's degree in Education-TESOL from The British University in Dubai, in 2018.

She has various research papers and a book chapter in the process of publishing. Her papers specialize in language analysis, second language acquisition, and applied linguistics for communicative purposes. 